\title{
第17回日本医学会総会衛生関係連合分科会会長挨拶
}

今回，第17回日本医学会総会が，名古屋で開催される 汇当り，第12分科会（日本衛生学会）・第13分科会（日 本民族衛生学会）・第36分科会（日本公盖衛生学会）・ 第39分科会（日本体力医学会）・第40分科会（日本産業 医学会）・第50分科会（日本農村医学会）法連合して学 会を開催するてとになりました。とのような衛生関係連 合分科会は, 既に 4 年前の第16回日本医学会総会におい て，4学会連合の形で試みられておりますが，今回は一 首交流の巾を搪げ，日本体力医学会・日本農村医学会が 参加し，更に前回，特別報告・シンポジァムのみに参加 した日本公笔衛生学会も多数の演題を提出しててれに加 わり, 日本農村医学会の一部の発表を除いて，6分科会 会員が渾然一体となって，共通の話題を討論し，相互の 新しい交流の場を持つ機会を持つにいたりましたてとは で同慶にたえない所ででざいます。

てれら 6 分科会は，それぞれ長い歴史と独自の理念を もって発展の一途を辿って参りましたが，一方，最近の 各分科会演題の中には共通の課題も極めて多く見られる ようになりました。同じ問題が異った学会で討議される ことにも勿論意味はありますが，同一演題にとりくむ各 学会の研究者が一堂に会して，異った立場からてれを討 議するととも，その問題を広い立場加ら理解し，問題の 本質を深く掘り下げる上で，極めて必要なととと思うの であります。

とのような意図のもとに連合分科会の隼備を進めて参 りましたが，ての連合学会の成果が，更に各分科会の新 しい分化に役立つであろうてとを私達は一阅期待してい る次第であります。

乙の学会開催の隼備に当っては，まず 6 分科会会員の 学問的交流の目的が充分果されるよう，共通のテーマを 見出すことに努力をし, 過去 3 年間の 6 分科会演題を綜 合して検討を加光，100題の共通かつ重要と思われる課 題を選定して，てれらの演題に対してアンケートにより 6 分科会会員の意見を求め, 1 題のメインシンポジァム ・6題のシンポジァム・46題の要望課題を決定いたしま した。6 題のシンポジフムは，おおおむ极 6 学会がそれぞ れ主役を演し，他の分科会がそれに参加する形をとり，
メインシンポジフムは，各分科会を代表する 6 人の演者 で構成し，てれによって学会の最後のしめくくりをして 戴くことになっております。

要望課題に対する演題283題は, 自由課題157題ととも に25会場に分かれ，すべて壁発表の形式で充分の時間を とって討議して戴くてとにいたしました。てのような形 侙の学会会場として南山大学を利用させて戴けたととは 極めて好都合ででざいました。

学会終了後, 座長及び座長補佐の方達に執筆して戴い て，学会記録“衛生関連学の進歩”を発刊することになっ ており，そのためにも，また学会当日の座長と演者の理 解を深めるためにも，新らしい陚みとして，報告内容に 関する一層詳細な解説書を提出して戴きました。

との学会の記録が明日からの研究への足がかりとなる ことを，私どもは念願しております。

実社会に生活する人々を対象とし，人々の健康の保 持，増進をはかるととを目的とする㦣生関連学は，治獠 医学，基礎医学に此べるなら，歴史が浅いだけに，その 研究の方法論においても，学問的体系においても，まだ きわめて問題が多い現状であります。そてで，4 年に一 度の 6 分科会交流の機会に, 私達は, 出来得る限りにお いて，学会に学問的な緟しさを加味してみたいとも考克 たのであります。

学会をお引き受けするに当って，学会のあり方を検討 し，あ光て新しい幾つかの試みを行なって参りましたた めに，会員諸氏にも多大ので苦労を戴くてとになりまし たが，それにもかかわらず，私達の意とする所を了とせら れ，心からので協力を賜わり，おかげでてのように立派な 多数の演題のもとで学会を開隻するにいたりましたてと 住，私達が何よりも嬉しく存じている所ででざいます。

てれらの学会の運営方針の決定から，準備一切にわた り，6 分科会長所属機関の研究者のみならず，東海地方 D各大学, 研究所, 衛生行政機関, 企業体衛生管理関係 の研究者は, 殆ど総動員で何らかの形でてれに参加さ れ，特に若い研究者達の意欲的な活動が常にてれをもり たててくれました。てれら多数の東海地方研究者達のチ ームワークの上にての学会の準情が進められましたてと 
を，感謝をこめてで報告いたしたいと思います。 最後に，本学会の開催に当り，一方なら妨で支援で協 力を戴いた 6 分科会事務局及び，経済的援助を睗わった
各界の方々に厚く御礼申し上げます。 昭和42年 4 月

\section{第17回日本医学会総会衛生関係 6 分科会連合学会}

$\begin{array}{llllll}\text { 第12分科会 } & \text { 第37回日本衛生学会会長 } & \text { 六 } & \text { 鹿 } & \text { 鶴 } & \text { 雄 } \\ \text { 第13分科会 } & \text { 第32回日本民族衛生学会会長 } & \text { 永 } & \text { 田 } & \text { 捷 } & \text { - } \\ \text { 第36分科会 } & \text { 第24回日本公䍃衛生学会会長 } & \text { 水 } & \text { 野 } & \text { 宏 } \\ \text { 第39分科会 } & \text { 第21回日本体力矢学会会長 } & \text { 奥 } & \text { 谷 } & \text { 博 } & \text { 俊 } \\ \text { 第40分科会 } & \text { 第40回日本産 業医学会会長 } & \text { 井 } & \text { 上 } & & \text { 俊 } \\ \text { 第50分科会 } & \text { 第16回日本農 村医学会会長 } & \text { 岡 } & \text { 本 } & \text { 正 } & \text { E }\end{array}$

